\title{
В АНГЛИЙСКОМ И РУССКОМ ЯЗЫКАХ КАК ИМПЛИЦИТНЫЙ СПОСОБ ЭМОЦИОНАЛЬНОГО ВОЗДЕЙСТВИЯ НА РЕЦИПИЕНТОВ (НА ПРИМЕРЕ КОММУНИКАЦИИ В СОЦИАЛЬНЫХ СЕТЯХ)
}

\section{COMPARISON OF CONVENTIONAL IMPLICATURES IN ENGLISH AND RUSSIAN AS AN IMPLICIT WAY OF EMOTIONAL IMPACT ON RECIPIENTS (ON THE EXAMPLE OF COMMUNICATION IN SOCIAL NETWORKS)}

\section{Maevskiy}

Summary: Waging war through "soft power» is the most humane response to the actions of an opponent, so at present, the modern political tactics of developed countries, if they are supposed to destroy the enemy, are focused on information impact based on the emotional determinants of a person. Taking into account the intellectual development of society, there are implicit sources that, by their psychological nature, cause more trust among the recipients. The relevance of referring to conventionals implicatures as an implicit method of emotional impact on recipients is determined by the fact that due to its hidden meaning, the statement is problematic to censor and, accordingly, it is difficult to bring the author of the comment to administrative or criminal responsibility. The inclusion in chats of various topics of conventionals implicatures, concentrated in discussions and comments in social networks, blogs, forums, etc., hypothetically integrates into the communication of users a text focused on destructurization or social cohesion within a particular issue depending on the goal of the addressee. While gigabytes of Internet space contain millions of utterances, the content of which is tracked by moderators using SEO algorithms, it is quite problematic to filter the semantic meaning of conventionals implicatures, and speech turns are an effective information weapon for this type of speech.

Keywords: conventionals implicatures, implicit, emotional impact, social networks, information warfare, virtual communication.

\author{
Маевский Владимир Михайлович \\ ассистент, соискатель, Российский университет \\ дружбы народов, г. Москва \\ maevskiy_vm@rudn.university
}

Аннотация: Ведение войны посредством «мягкой силы» - это наиболее гуманный ответ на действия оппонента, поэтому современная политическая тактика развитых государств, если предполагается уничтожение противника, сосредоточена на информационном воздействии, опирающемся на эмоциональные детерминанты человека. Релевантность обращения к коммуникативным импликатурам, как имплицитному способу эмоционального воздействия на реципиентов, обусловлена тем, что благодаря скрытому смыслу, высказывание проблематично подвергать цензуре и сложно привлекать к административной или уголовной ответственностям его автора. Включение в чаты разнообразной тематики коммуникативных импликатур, сконцентрированных в обсуждениях и комментариях в социальных сетях, блогах, форумах и пр., гипотетически интегрирует в коммуникацию пользователей текст, ориентированный на деструктуризацию или сплочение общества в рамках той или иной проблематики - В зависимости от цели адресанта. В Интернет-пространстве миллионы высказываний отслеживаются модераторами, но фильтровать смысловое значение коммуникативных импликатур проблематично, соответственно, данного типа речевые обороты являются эффективным информационным оружием.

Ключевые слова: коммуникативные импликатуры, имплицитный, эмоциональное воздействие, социальные сети, информационная война, виртуальная коммуникация.

\section{Введение}

И скусство информационной войны изначально использовали в устной форме, затем - в листовках, далее - в СМИ. Сегодня в действие включены технотронные средства - киберпространство. «Информационная, в том числе, информационно-психологическая, война сегодня стала доминирующим средством мировой политики» [2, с. 9]. Преимущественно, данный тип «мягкой силы» осуществляется через Интернет, что обусловлено количеством пользователей виртуального пространства, насчитавшем в 2020 г. «4,54 млрд людей (64\% от всего населения планеты). Из них на январь 2020 г. 3,80 млрд составили пользователи социальных сетей, количество которых выросло на 9\% по сравнению с 2019 г. - 321 млн новых пользователей за год» [8]. Прирост пользователей детерминирован ведённым режимом самоизоляции / карантина - вследствие ограничения контактного общения из-за пандемии коронавируса Covid-19 людям пришлось осваивать дистантные средства коммуникации. 


\section{Исследовательская проблема}

Проведён мониторинг социальных русскоязычных и англоязычных сетей: коммуникативных импликатур (далее - КИ), используемых в комментариях к постам, содержащим освещение общественно-значимых проблем или оценочные к ним высказывания.

Цель - анализ коммуникативных импликатур («импликатур дискурса» [10, с. 99]), имплицитно воздействующих на эмоциональные детерминанты социума.

\section{Анализ материала}

Анализ «анатомии» коммуникативных импликатур в чатах продемонстрировал, что благодаря своей краткости и скрытым коннотациям коммуникативные импликатуры в различного рода кибер-беседах предельно популярны. При этом на русскоязычных сайтах обсуждение политических, эпидемиологических или других социально-значимых проблем посредством комментариев доступно практически везде. Например, в настоящий момент самой актуальной остаётся проблема пандемии коронавируса, комментарии пользователей о ней можно встретить как в частных переписках, так и на официальном государственном сайте Coronavirus (covid-19) https://coronavirus-monitor.ru/, на медицинском портале Яндекс.Здоровье, в одноимённой рубрике «Комсомольской правды», и, конечно же, в Instagram, Facebook, vk.com (ВКонтакте) и пр. В англоязычных контентах достаточно проблематично найти сайты, где можно в открытую обсуждать эпидемиологическую обстановку, за исключением социального сервиса Quora [23] и социальных сетей.

В настоящий момент нет еще четкого представления о происхождении Covid-19, поэтому существуют разные мнения относительно данного вопроса:

1. одни эксперты полагают, что это биологическое оружие массового поражения (КИ «Если это биологической оружие то его делал студент для курсовой» [7], смысловое значение: адресант сомневается в достоверности данной гипотезы, о чём свидетельствует фраза «его студент сделал для курсовой»- КИ в значении «создано неграмотным специалистом»);

2. другие относят коронавирус нового типа к медицинскому феномену, возникновение которого обусловлено бесконтрольным потреблением антибиотиков и других лекарств, используемых населением в качестве самолечения, что ослабило коллективный иммунитет [1]. В комментариях к статьям о данном феномене множество солидарных высказываний. Некоторые русскоязычные пользователи дают рекомендации по лечению (напр., см. рис. 1), англоязычные пользователи не берут на себя такую ответственность.

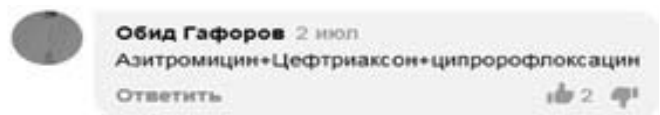

Рис. 1. Комментарий к газетной статье Medical Insider

В КИ «Азитромицин+Цертриаксон+ципророфл оксацин» [5] представлена одна из формул лечения при коронавирусе, которую предлагает неизвестный пользователь, представившийся именем Обид Гафоров.

3. третьи приписывают данное явление к дестабилизации экологии планеты:

8 Vinod Dawda, Lived in Africa, India and Europe. Fascinated by the history Updated June 17. Author has 509 answers and $723.1 \mathrm{~K}$ answer views

Let us be very realistic. The COVID virus will NOT end in any near future. I have drawn some reasonable conclusions based on some understanding of viruses and epidemics. I will not be too technical as it hardly adds much to the appreciation of huge capability of nature.

Рис. 2. Гипотезы возникновения и течения пандемии Covid-19. Quora

"The COVID virus will NOT end in any near future... We have silently watched nature being ravaged indiscriminately by humans» [23] (@Vinod Dawda). («Bupyc COVID не закончится в ближайшем будущем... Мы молча наблюдали за тем, как люди без разбора разоряют природу»). Значение КИ «We have silently watched nature being ravaged indiscriminately by humans»: человек долго разорял природу, теперь природа уничтожает человечество в ответ.

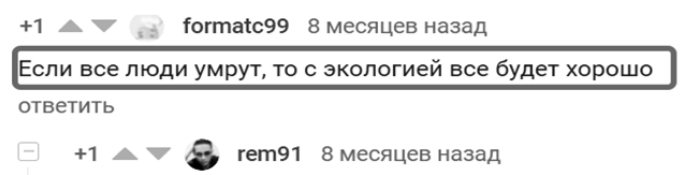

Да можно просто в каменный век вернуться, экология будет шикарная. А мы всей толпой за мамонтом будем бегать. ответить

$$
\begin{aligned}
& 0-\nabla \text { Vitaliy89Alive } 7 \text { месяцев назад } \\
& \text { За мистером пу. } \\
& \text { ответить } \\
& 0<\nabla \text { formatc99 } 8 \text { месяцев назад } \\
& \text { Планета в порядке, это людям 1здец } \\
& \text { птветить }
\end{aligned}
$$

Рис. 3. Корреляция коронавируса с экологической дестабилизацией. Pikabu

Данные КИ можно прочесть в социальной сети Пикабу. Значение КИ «Если все люди умрут, то с экологией все будет хорошо» [3] и «Планета в порядке, это людям пu**ец» [3] - «если люди вымрут от пандемии, экология планеты восстановится».

4. четвертые объясняют возникновение Covid-19 с

1 Сохранена грамматика, пунктуация и стилистика цитируемого материала. 
Наталья: А может правда то что написано в скрижалях Джорджии, и идёт исполнение заповедей, особенно первой B(2) $P(2) 02.022020 \cdot 20: 40$ ОТВетИTЬ

Рис. 4. Гипотеза возникновения коронавируса Covid-19

позиции религиоведения (наказание человечества за грехи [12; 22]) (см. рис. 4) и пр.

В данной КИ речь идет о десяти заповедях, написанных на каменном монументе в штате Джорджия (США) [11, с. 354], гласящие о том, что «земное население, не должно превышать 500.000.000 человек» (в настоящий момент эта цифра достигла 7763035303 человек), а также, что люди не должны стать «раковой опухолью для Земли». Соответственно, автор комментария имеет ввиду, что коронавирус мог стать той карательной силой, о которой идет речь в «Скрижалях Джорджия», соответственно, Covid-19 выступает в роли рычага, содействующего воссозданию равновесия и баланса в природе.

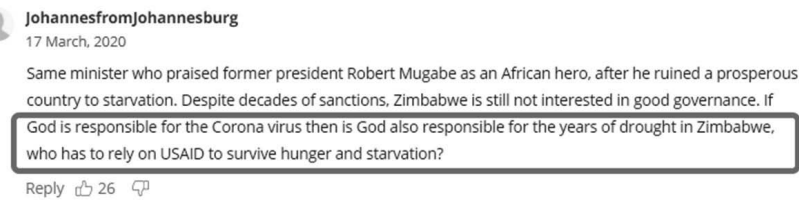

Рис. 5. Гипотеза возникновения коронавируса Covid-19. Fox News

$\mathrm{K} И$ «If God is responsible for the Corona virus then is God also responsible for the years of drought in Zimbabwe, who has to rely on USAID to survive hunger and starvation?» - «Если Бог несет ответственность за коронавирус, то Бог также несет ответственность за годы засухи в Зимбабве» в значении: мнение Robert Mugabe о том, что коронавирус - это Божья кара, ошибочно и не соответствует христианским воззрениям.

Достаточно часто использование КИ встречается при обсуждении политики, активно корректирующийся по всему миру в связи с пандемией. По мнению многих исследователей - Covid-19 - это рукотворное оружие, направленное на истребление определённых народов и на провоцирование «массового психоза» - своего рода, психоактивная война, реализуемая посредством СМИ, т.е. информационное оружие, гибридизированное с биологическим оружием. Таким образом, в различных слоях населения с разным мировоззрением и религиозными верованиями, а также уровнем интеллектуального развития, возникает определенная реакция на пандемию. При этом КИ нередко коррелируют с политическими воззрениями пользователей сети Интернет. Что характерно, в англоговорящих и русскоговорящих странах имплицитная реакция людей отличается, а именно, пользователи русскоязычного контента активно обсуждают эпидемиологическую ситуацию, а англоговорящие пользователи более сдержаны. Полагаем, строгая законодательная система и высокий уровень ответственности за свои слова и поступки сформировали привычку анлоговорящих граждан не выставлять свои оценочные высказывания на всеобщее обозрение. Тем не менее, в различных уголках планеты можно встретить разную реакцию на пандемию:

1. в одних регионах возникает паника: «lt is not the end of the world though humans overestimate their ability and importance in the grand scheme of universe! Humans are totally expendable when nature decides it had enough» [23] - Это не конец света, хотя люди переоченивают свои возможности и значение в великой схеме мироздания! Люди полностью расходуются, когда природа решает, что с неё достаточно. - Значение КИ: если будет катаклизм (в качестве которого может стать коронавирус Соvid-19), у человечества может не остаться шансов на выживание.

2. другие предельно скептически настроены: Coronavirus will never, ever be over, just like Influenza will never, ever be over. Since that fateful day when somebody in Wuhan decided to snack on a bat, or a snake, or a wolf or whatever it was, the course of history was changed forever (๔Joe Berah) [23]. (Коронавирус никогда, никогда не закончится, как и грипп никогда не закончится. С того рокового дня, когда кто-то в Ухане решил перекусить летучей мышью, змеей, волком или кем-то еще, ход истории изменился навсегда). Значение КИ «...to snack on a bat, or a snake, or a wolf or whatever it was, the course of history was changed forever»: виновники распространения коронавирусной инфекции нового типа - китайцы, которые опрометчиво едят тех животных, которых есть неестественно для природы человека, за что жители Китая и вся планета сильно поплатилась.

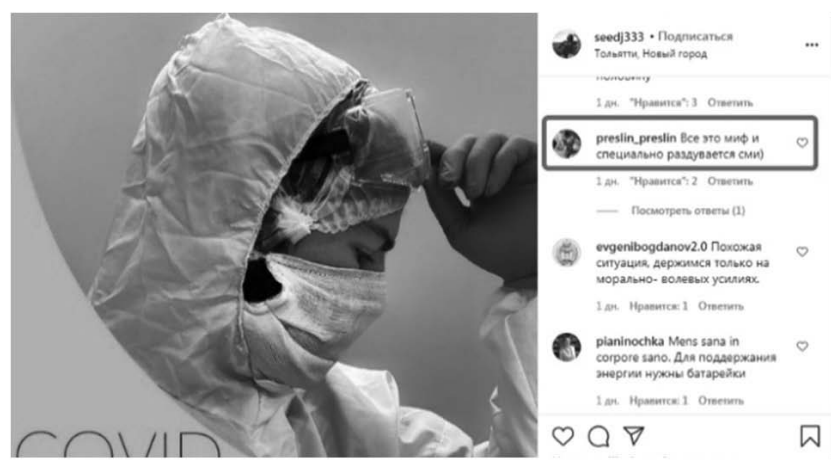

Рис. 6. Обсуждение пандемии Covid-19. Instagram

Значение КИ «Всё это мифр и специально раздувается сми» [9] - данным высказыванием адресант пытается сказать, что коронавирусной инфекции Covid-19 не существует, а население планеты обмануто СМИ, которые «вы- 
полняют приказ властей», целью чего является «тотальный контроль граждан» - теория чипизирования людей всего мира. Таким образом, достигаются цели консциентальной войны (вид информационной войны): разрушение ценностных установок народонаселения противника, а именно: подрыв доверия к СМИ опирается на подрыв доверия к властям. Недоверие к верховному руководству влечёт за собой революционные настроения.

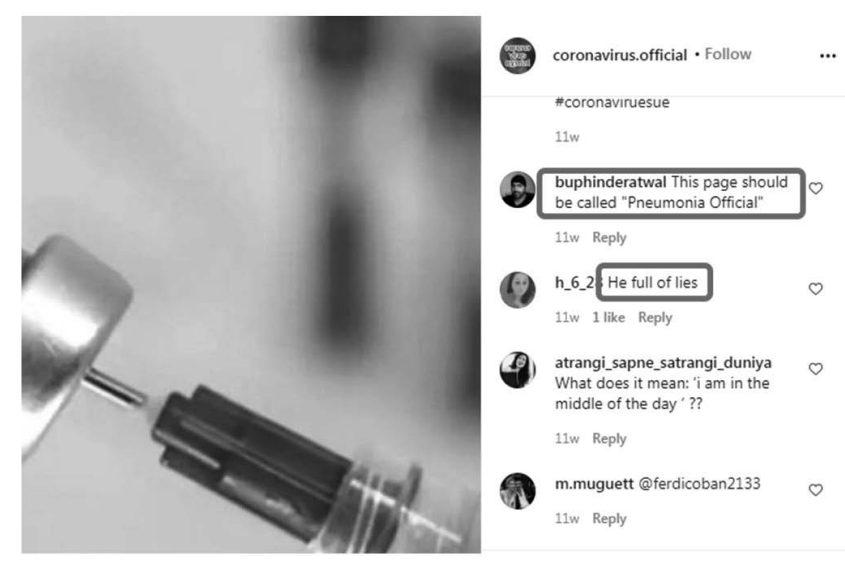

Рис. 7. Обсуждение вакцины от Covid-19. Instagram

«This page should be called «Pneumonia Official» [14] «Эта страница должна называться «офичиальный сайт пневмонии» - данная КИ ставит под сомнение наличие коронавируса Covid-19, а именно, автор высказывания делает акцент на том, что пандемии не существует, а люди просто заболевают пневмонией.

Далее представлены оппозиционные мнения относительно российской вакцины от коронавируса Covid-19 - «Спутник V». Очевиден имплицитный контекст оппозиционных настроений комментаторов, что является характерным признаком контентной войны («информационно-психологической войны, нацеленной на изменение свойств человеческого интеллекта» [2, с. 62]):

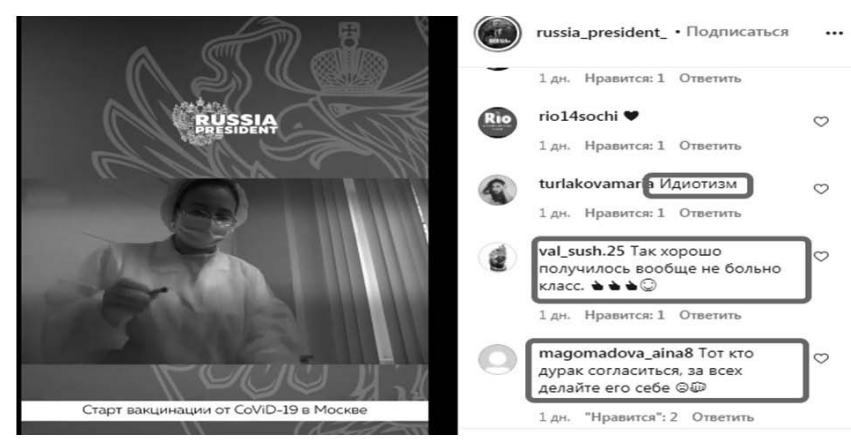

Рис. 8. Видео в Instagram о вакцинации населения России от Covid-19

КИ «Идиотизм» и «Тот кто дурак согласиться, за всех делайте его себе» ${ }^{2}$ [21] имеют оппозиционный характер и являются примером контентной войны, ориентированной на интеллектуальное поражение народа. В данных цитатах сохранена пунктуация и грамматика. Вполне возможно, что аграмматизмы могут включаться автором или инициатором в текст комментария сознательно, чтобы завуалировать намерение эмоционально дестабилизировать читательскую аудиторию и, в то же время, создать впечатление искренности идеологии высказывания.

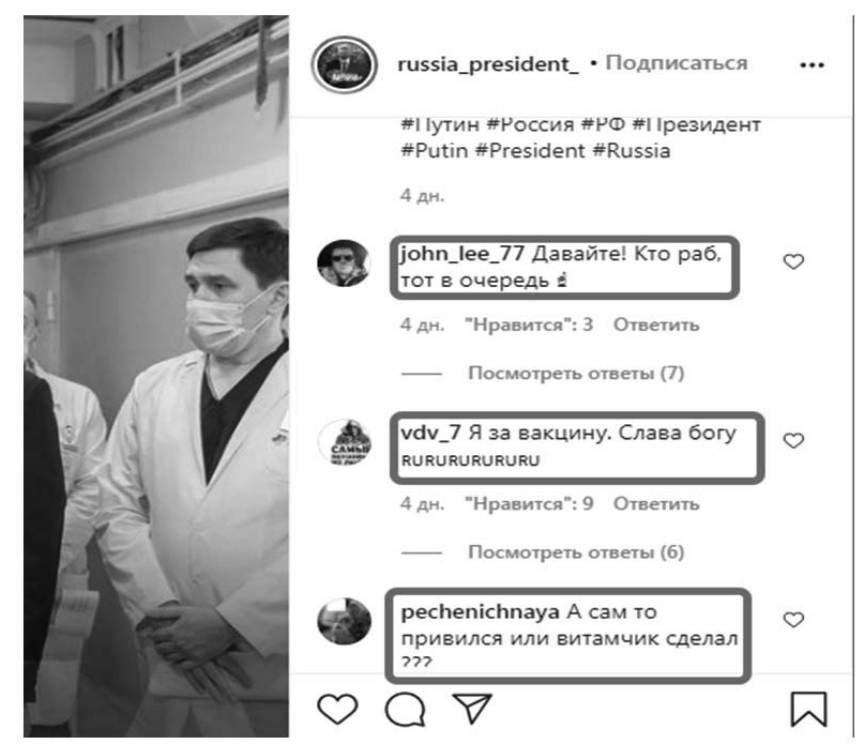

Рис. 9. Пост в Instagram о вакцинации населения России от Covid-19

КИ «Так хорошо получилось вообще не больно класс» характеризует ощущения после вакцинации коммуниканта от Covid-19, тем самым, мотивируя доверять населению спасение своей жизни от коронавируса медицинскому персоналу и призывая сделать вакцину российского производства. КИ «Давайте! Кто раб, mom в очередь» [21] - в значении: правительство России создало вакцину с целью чипизировать население и, таким образом, осуществлять тотальный контроль за россиянами, тем самым, превратив их в рабов. КИ «А сам то привился или витаминчик сделал???» [21] подразумевает, что вакцина создана с целью чипизирования народов России, а богатые слои населения ставят себе другую прививку, не включающую в свой компонент чип для слежения за объектом.

Мониторинг социальных сетей также продемонстрировал, что многие пользователи относятся к пандемии с юмором. Данный феномен позволяет разгрузить эмоциональное напряжение народонаселения планеты - это положительный фактор, действующий по принципу гелотологии, т.е. имеющий психотерапевтический эффект (см. рис. 10):

2 Сохранена грамматика, пунктуация и стилистика цитируемого материала. 

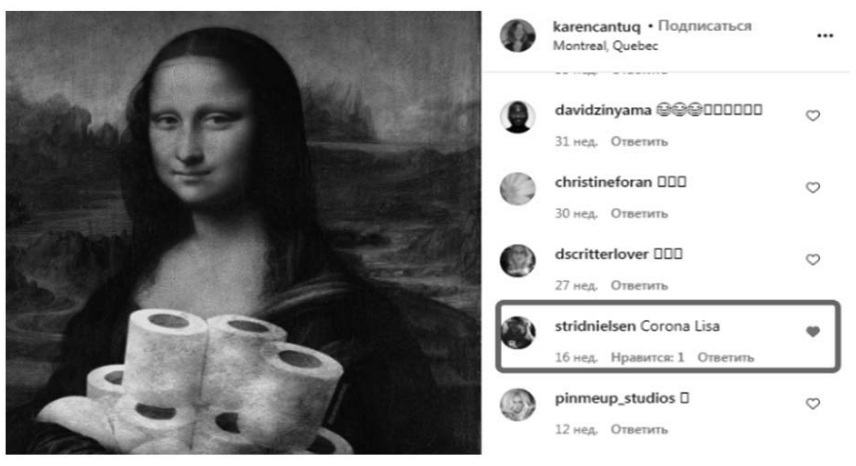

Рис. 10. Юмористическая карикатура под названием «Ready to wipe out coronavirus» [18] - «Готова cmepemь коронавирус», ориентирована на тех, кто во время пан-

демии чрезмерно запасался туалетной бумагой

КИ «Corona Lisa» [18] - - каламбур из дефиниций «Коронавирус» и «Мона Лиза» в значении: Covid-19 завоевал популярность, как картина «Мона Лиза» Леонардо да Винчи. Имплицитность высказывания: основная масса населения мира настолько запугана, что уже не думает о высоких ценностях, а преимущественно сосредоточена на мерах выживания.

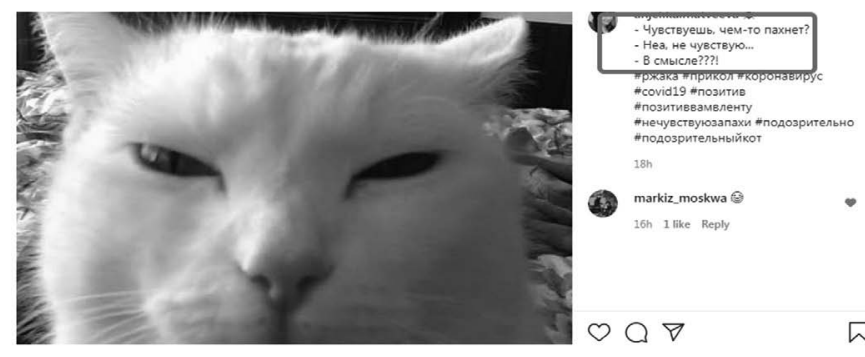

Рис. 11. Юмористическая карикатура об отсутствии обоняния при заболевании коронавирусной инфекцией

Имплицитность КИ «Чувствуешь, чем-то пахнет?» сосредоточена на главном симптоме Covid-19 - аносмии (отсутствии возможности чувствовать запахи), а также включает упоминание об истеризированном обществе, фобическое состояние которого опирается на страх заболеть коронавирусом - ипохондрию и нозофобию. Иронизирование нетерпимости к больным во время пандемии является профилактикой массового психоза, возникшего из-за Covid-19, и грамотным ответом на последствия психоактивной (информационной) войны.

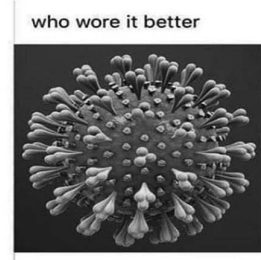

Coronavirus

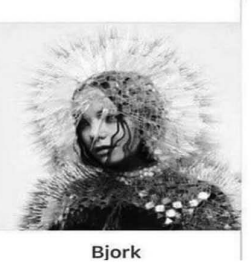

Bjork

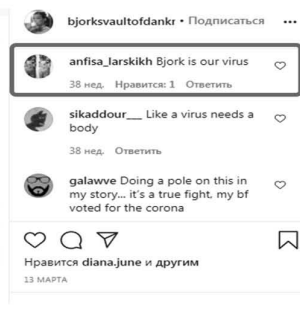

Рис. 12. Who wore it better [13] («Кому что лучше идёт). Instagram
КИ «Like a virus needs a body» [13] - «Как же вирус нуждается в теле» - очень концептуально, имплицитное значение сосредоточено на том, что коронавирус Covid-19 нашёл своего хозяина (из животного перекочевал в организм человека), которого может прекрасно паразитировать.
California COVID-19

lockdown measures are met with skepticism but may offer the best hope

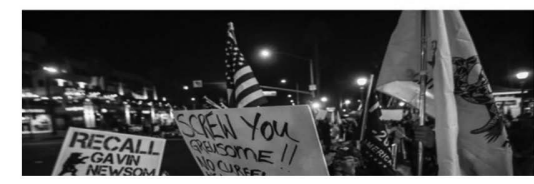

Pис. 13. California covid-19 lockdown measures are met with skepticism but may offer the best hope [15]

(«Калифорнийские меры по блокировке covid-19 встречены скептически, однако, может они к лучшему»)

Ироничность детерминирована критической ситуацией, в которой сейчас находятся все страны - больницы переполнены пациентами, но люди всё равно опрометчиво собираются в толпы для демонстраций, хотя рекомендовано дистанцироваться. Также КИ обналичивает недальновидность калифорнийцев; эмоциональное напряжение «подчёркивается» многоточием, иронизированно указывая на то, что люди идут на демонстрацию, не потому, что они живут в демократическом обществе, а по глупости. Данная КИ - признак информационной войны: «Ментальные (психологические) - это контентные войны, имеющие своей целью изменение массового, группового и индивидуального сознания или психики» [2, с. 8]. Коннотация КИ: один пласт населения относится ответственно к режиму самоизоляции и выполняет рекомендации ВО3, а другие не заботятся об этом, что вызывает конфронтации.

Имплицитный способ эмоционального воздействия на реципиентов зависит от предмета и объекта воздействия, мотивации адресанта. Данные КИ «работают» в нескольких направлениях:

1. экономическое (с целью наживы);

2. психоэмоциональное - деструктуризация социума (способ разрушения государства изнутри);

3. оппозиционное (способ смены лиц правительства на новое верховное руководство) и т.д. Политологи и психологи с целью стабилизации ситуации осуществляют мониторинг данных сообщений посредством SEO-алгоритмов, модерируют контент и дискутируют в качестве обычных пользователей-коммуникантов. Хейтеры, тролли и оппозиция усугубляют эмоциональное напряжение, вызывая посредством КИ революционные волнения, вплоть до инициирования смены 
руководства.

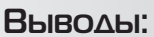

1. современные КИ в Интернете - эффективный имплицитный способом эмоционального воздействия на реципиентов;

2. в отличие от рекламы, имплицитные КИ ориентированы на навязывание чужих целей, идей, концепций, являясь оружием информационной войны;

3. посредством КИ специалисты могут провоцировать народные волнения или помогать стабилизи- ровать социальные взаимоотношения;

4. главной отличительной особенностью КИ в английском и русском языках в социальных сетях является активность пользователей: в англоязычных источниках комментарии адресантов малочисленны, сдержанны, очень редко оппозиционны; пользователи русскоязычного контента откровенно высказывают свою гражданскую позицию, позитивное или негативное мнение, принимают активное участие в дискуссиях; (5) выводы можно использовать в борьбе с кибер-терроризмом, психологическим давлением или когнитивной деструктуризацией социума.

\section{ЛИТЕРАТУРА}

1. В В03 предупредили о риске новой пандемии из-за неконтролируемого приема антибиотиков. ТАCC. Статья от 30.11.2020. URL: https://tass.ru/ obschestvo/10132455. Date: 08.11.2020.

2. Воронова, 0.Е. Современные информационные войны: типология и технологии [Текст]: монография / 0.Е. Воронова; Министерство образования и науки РФ, ФГБО УВО «Рязанский государственный университет им. С.А. Есенина». - Рязань: РГУ им. С.А. Есенина, 2018. - 187 с.

3. Коронавирус и экология: как новый вирус меняет планету. Pikabu. Статья: апр. 2020. URL: https://pikabu.ru/story/koronavirus_i_yekologiya_kak_novyiy_ virus_menyaet_planetu_7296331. Дата обращения: 08.12.2020.

4. Крамченко, В. Коронавирус Covid-19.Яндекс.Здоровье. URL: https://yandex.ru/health/turbo/articles. Date: 07.12.2020.

5. Лечат ли коронавирусную инфекцию антибиотиками? Medical Insider Статья от 2 июля 2020. URL: https://yandex.ru/ turbo/medicalinsider.ru/s/news/lechatli-koronavirusnuyu-infekciyu-antibiotikami/.

6. Лукашенко объяснил, почему в Белоруссии не ввели карантин. Статья от 27.03.2020. URL: https://ria.ru/20200327/1569242093.html. 08.12.2020.

7. Профессор Михаил Бала: вирус имеет все признаки биологического оружия. Pikabu. URL: https://pikabu.ru/story/professor_mikhail_bala_virus_imeet_ vse_priznaki_biologicheskogo_oruzhiya_7844880. Date:08.12.2020.

8. Сергеева, Ю. Вся статистика интернета на 2020 год - цифры и тренды в мире и в России. WebCanape. Статья от 03.02.2020. URL: https://www.web-canape. ru/business/internet-2020-globalnaya-statistika-i-trendy/.07.12.2020.

9. \#стопкоронавирус. Instagram. Date: 07.12.2020.

10. Филологические науки. Вопросы теории и практики. 2018. - № 7 (85), ч. 1. - 216 с.

11. Фоер, Д. Atlas Obscura. Самые необыкновенные места планеты / Д. Фоер, Д. Тюрас, Э. Мортон; пер. с англ. [Н. Беловой и др.]. - М.: Манн, Иванов и Фербер, 2018. - 470 c.

12. Этот странный коронавирус: кара Божья или оружие? Большой Ростов. Статья от 01.02.2020. URL: https://big-rostov.ru/etot-strannyj-koronavirus-karabozhya-ili-oruzhie/. Дата обращения: 08.12.2020.

13. bjorksvaultofdankmemes. Instagram. Date: 08.12.2020.

14. coronavirus.official. Instagram. Date: 08.12.2020.

15. coronavirus.update. Instagram. Date: 08.12.2020.

16. coronavirus.update. Date: 05.12 .2020 .

17. Fedschun, T. Coronavirus is punishment for sanctions, US must'also feel the pain', Zimbabwe official says. March 16, 2020. Fox News. URL: https://www.foxnews. com/world/coronavirus-us-zimbabwe-sanction-pain-viral-outbreak. Date: 08.12.2020.

18. Karencantuq. Instagram. Date: 07.12.2020.

19. lukashenko_president. Instagram. Date: 07.12.2020.

20. President Lukashenko says what will/might happen after coronavirus. 07 anp. 2020. URL: https://www.youtube.com/watch?v=wuGUvdnAUMw.

21. russia_president_Instagram. Date: 07.12.2020.

22. Schnell, L. Is the coronavirus an act of God? Faith leaders debate tough questions amid pandemic. USA TODAY. Apr 2, 2020. URL: https://www.usatoday.com/story/ news/nation/2020/04/02/coronavirus-god-christain-jewish-muslim-leaders-saying-deadly-plague/5101639002/. Date: 08.12.2020.

23. When will the COVID-19 virus end? Quora. URL: https://www.quora.com/When-will-the-COVID-19-virus-end. Date: 04.12.2020.

( ) Маевский Владимир Михайлович (maevskiy_vm@rudn.university). 